\title{
The Exploration of Chlorophyll Content of Various Plants in City Forest of Malabar Malang
}

\author{
Roimil Latifa, Samsun Hadi, Endrik Nurrohman \\ Biology Education Department, Faculty of Teacher Training and Education University of \\ Muhammadiyah Malang, Indonesia \\ email: roimillatifa20@gmail.com
}

\begin{abstract}
This research aimed at investigating chlorophyll content of various plants growing in the city forest of Malabar Malang. A descriptive quantitative method was employed as the research design. This research was conducted from April to August 2019 in the city forest of Malabar and Biology Laboratory University of Muhammadiyah Malang. The data were analyzed using Microsoft Excel. There were three steps of the research: a) surveying the research location; $b$ ) taking samples of each leaf; and c) laboratory testing. Laboratory testing comprised some stages: a) weighing each leaf sample at 0.3 gram, grounded and dissolved in $80 \%$ acetone; b) filtering by utilizing filter paper, and c) testing using spectrophotometer with the wavelengths of $645 \lambda$ and $663 \lambda$, respectively to result in absorbance value. The results of absorbance value were tabulated into a specific formula to find out the content of chlorophyll $a$, chlorophyll $b$, and the total chlorophyll of each leaf sample. This current research has revealed that regarding the average scores, chlorophyll-a was the highest in Averrhoa bilimbi leaf $(35.848 \mu \mathrm{g} / \mathrm{ml})$, and the lowest is in Averrhoa carambola leaf $(17.857 \mu \mathrm{g} / \mathrm{ml})$. The average score of chlorophyll $b$ was the highest in Tabebuya leaf $(58.862 \mu \mathrm{g} / \mathrm{ml})$, and the lowest is in Norfolk pine leaf $(9.124$ $\mu \mathrm{g} / \mathrm{ml})$. As for the total average of chlorophyll content, the highest content was extracted from Tabebuya leaf $(91.737 \mu \mathrm{g} / \mathrm{ml})$, and the lowest was in Norfolk pine leaf $(28.517 \mu \mathrm{g} / \mathrm{ml})$.
\end{abstract}

Keywords: Exploration, City Forest of Malabar, Leaf Chlorophyll.

\section{INTRODUCTION}

City forest is an example of green open spaces consisting of trees growing in a piece of land in a city or its surrounding (Regulations No. 26 the Year 2007), which shapes are pathfollowing, distributed or concentrated, or overlapping structurally, and thus it resembles that of natural forest, capable of providing habitat for sustaining the lives of animals, and provides environment which is healthy, cool, and aesthetic (Irwan, 1994).

Malabar city forest lies at the heart of Malang city (Alfian \& Kurniawan, 2010). Inside, grow various types of plants, such as Albizia chinensis, Chamaedorea sp, Elais guinensis, Pithecellobium dulce, Averrhoa bilimbi, Gmelina arborea, Polyalthia longifolia,
Chamaedorea sp, Chrysophyllum cainito, Mimusoph elengi, Ficus maclelandii. Vegetation growing in Malabar city forest is characterized by its diverse types, trunk diameters, height, and age of the plants, as well as the capability of carbon absorption (Latifa et al., 2018).

City forest, by its shapes, can be classified into three categories, namely 1) concentrated or overlapping, which indicates that the vegetation is concentrated in an area with a minimum of 100 trees with close and irregular planting range, 2) distributed, which indicates that the city forest's vegetation does not have clear planting pattern, growing in scattered areas and forming small groups of vegetation, 3) path-

Bioedukasi Vol. XVII. No. 2 October 2019 
following, which indicates that the vegetation grows following a certain path, including straight or curving path, following the shape of a river, road, shore, sewage system, and others (Irwan, 1994). Malabar city forest is classified as a forest with a distributed shape.

A city forest has a crucial role in maintaining the ecological balance of an urban area. The intrinsic or primary functions of a city forest are producing oxygen (Sesanti, 2012), cultivating germplasm, shielding of and filtering solid particles in the air, absorbing lead particles, reducing acid rain, absorbing carbon monoxide and carbon dioxide, conserving groundwater, improving the city's aesthetic look, and providing habitat for the birds (Dahlan, 1992).

Other benefits of having a city forest, according to Grey \& Deneke (1978) are conserving the soil, water system, maintaining climate amelioration, as well as controlling air pollution. To maintain the existence of the city forest, the efforts that can be done are cultivating the vegetation growing inside the forest (Hakim, 1991).

There are external and internal factors that contribute to the growth of a plant. The external factors primarily are the soil, humidity, light, nutrition, and water supplies. The internal factors are genes, hormones, anatomical, and morphological structures of the plant, and the chlorophyll content (Sasmitamihardja \& Siregar, 1997). Plant leaf, among other plant organs, grow and develop (Nurrohman et al., 2017). Plant leaf contains many substances, including secondary metabolic compounds, vitamins, minerals, fibers, and chlorophyll (Campbell, 2003). Chlorophyll is a green pigment of a chloroplast (Kurniawan et al., 2010).
The chlorophyll presence and content are crucial for a plant, because chlorophyll has important roles in the plant's biochemical process, especially in photosynthesis and production of energy (Campbell, 2008), and is an important pigment, contained in the thylakoid membrane, for sunlight absorption. Chlorophyll is also a catalyst for photosynthesis; a green pigment which is important for the tissue of all green plants (Salisbury \& Ross, 1995), and is produced by proplastid, which is a growing, small, colorless or slightly colored plastid with no inside membrane (Salisbury \& Ross 1991).

Chlorophyll strengthens the cells and chemically neutralizes pollutants because chlorophyll is rich in nutrition and oxygen, which can neutralize or negate free radical activities. Chlorophyll has a crucial role in maintaining the cleanliness of the air (Faqir, 2010) and can improve the air quality because of its contribution to improving the physiological function and process of the plant (Campbell, 2003). Proplastids split when an embryo develops and becomes chloroplast when the leaf and trunk develop (Salisbury \& Ross 1991).

Chlorophyll is an important component of a chloroplast, and the chlorophyll content is positively correlated to the photosynthesis rate $(\mathrm{Li}$ et al., 2006). High chlorophyll content in a leaf improves the plant's capacity in performing photosynthesis (Setiawati et al., 2016). Chlorophyll is synthesized in a leaf, and it can catch the sunlight, which is needed at different levels considering the plant's species. Chlorophyll synthesis is influenced by various factors, such as sunlight, sugar or carbohydrate content, water, temperature, genetic factors, and soil nutrients, such as $\mathrm{N}, \mathrm{Mg}, \mathrm{Fe}, \mathrm{Mn}, \mathrm{Cu}$, 
$\mathrm{Zn}, \mathrm{S}$, and $\mathrm{O}$ (Hendriyani \& Setiari, 2009).

Trees can filter and consequently reduce the level of carbon dioxide in the air through the absorption of $\mathrm{CO} 2$, which is needed in the photosynthesis process (Dolman et al., 2003). The capacity for conducting the photosynthesis process determines the amount of oxygen produced, which is crucial for improving the air quality. Healthy air will sustain the better living quality of the surrounding population and fulfill the general aims of city planning. There are two general aims of city planning, namely, to create a sustainable environment efficiently and to create an environment that is enjoyable, comfortable, safe, and attractive (Page \& Seyfriend, 1970).

Reflecting on the discussion above, chlorophyll in plant leaf is important for both the plant and its surrounding environment. Therefore, research conducted to measure the chlorophyll level of plants growing in the city forest of Malabar is necessary to be carried out. This research aimed to find out the chlorophyll content of the plants found in the city forest of Malabar, Malang.

\section{RESEARCH METHOD}

\subsection{Type of research}

The research is descriptive quantitative research.

\subsection{Location and Time}

The research was conducted in the city forest of Malabar as the sampling location and the Biology Laboratory of University Muhammadiyah Malang as the location to analyze the chlorophyll content. The research was conducted from April to August 2019.

\subsection{Research Procedures The steps in conducting the research}

1) Research Preparation

a. Observing the sampling location in the city forest of Malabar, Malang.

b. Preparing the research instruments and materials, including spectrophotometer, analytic weighing device, mortar and pestle, glass cone, measuring glass, test tube, test tube rack, Petri dishes, pipette, spatula, acetone, distilled water, filtering paper, aluminum foils, tissues, labeling paper, tree calipers, soil tester, thermo-anemometer, and lux meter.

\section{2) Research Procedures}

a. The leaf sample of each plant was picked and placed inside a plastic bag.

b. For sample testing using spectrophotometer UV-Vis, the steps are as follow:

1. Preparing $80 \%$ acetone.

2. Preparing and weighing the sample at 0.3 grams.

3. Grounding the sample using mortar and pestle until the pulp is formed.

4. Adding $15 \mathrm{ml} 80 \%$ acetone into the grounded and homogenized sample.

5. Filtering using filter paper and then placing it in a test tube.

6. Giving a label to each test tube

7. Reading the chlorophyll a, chlorophyll b, and total chlorophyll contents based on the absorbance at $\lambda 645$ and $\lambda 663$ and the formula requirements. 


\subsection{Data Collection Method}

To calculate the chlorophyll a, b, and total chlorophyll contents, the formula below was used.

1. Chlorophyll $\mathrm{a}=\left(12,7^{*} \lambda\right.$ 663) $(2,69 * \lambda 645)$.

2. Chlorophyll $\mathrm{b}=(22,9 * \lambda$ 645) $(4,68 * \lambda 663)$

3. Total Chlorophyll $=(8,02 * \lambda 663)+$ $(20,2 * \lambda 645)$

\subsection{Data Analysis}

The data were analyzed using descriptive statistical averages.

\section{RESULTS AND DISCUSSION}

Figure 1 presents the sample preparation for each leaf. Figures 2, 3,
4, 5, 6, and 7 present the testing results of chlorophyll a, chlorophyll b, and total chlorophyll contents of every plant found and sampled from Malabar city forest.

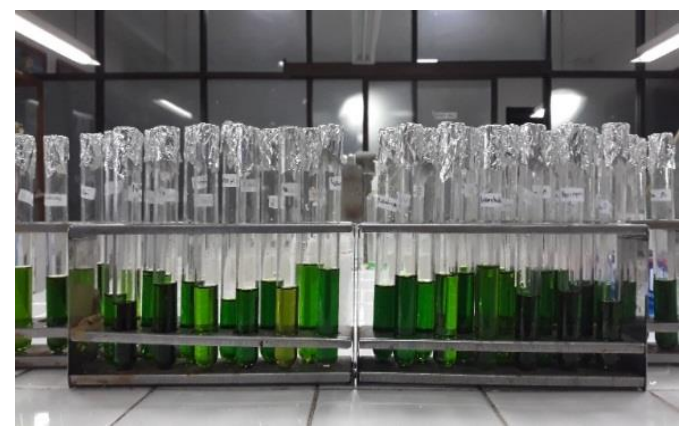

Figure 1. Preparation of leaf sample

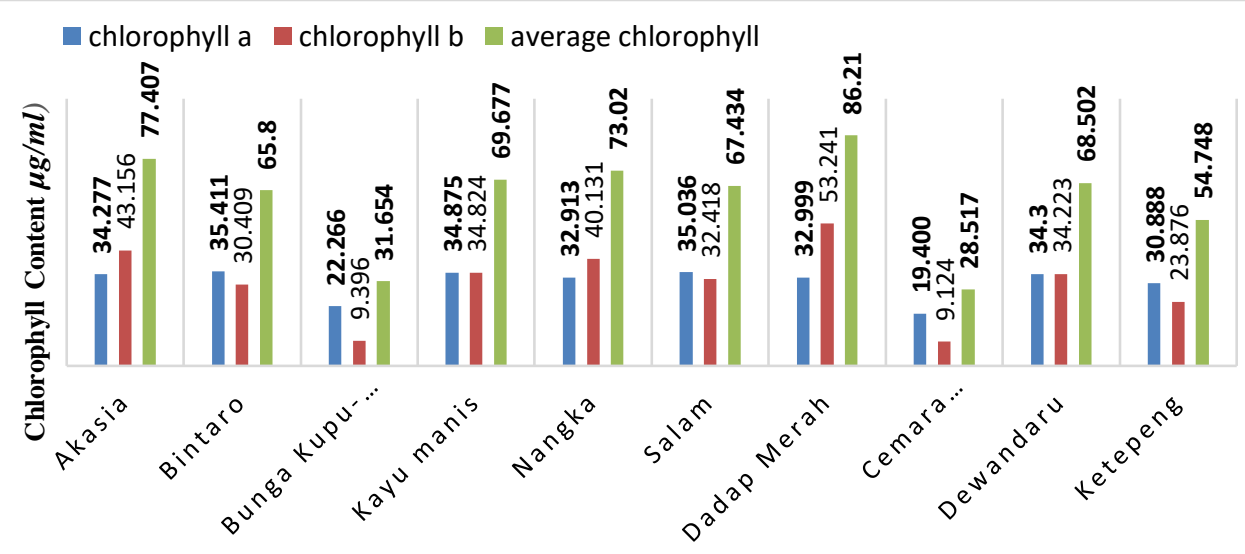

Figure 2. Diagram of leaf's chlorophyll

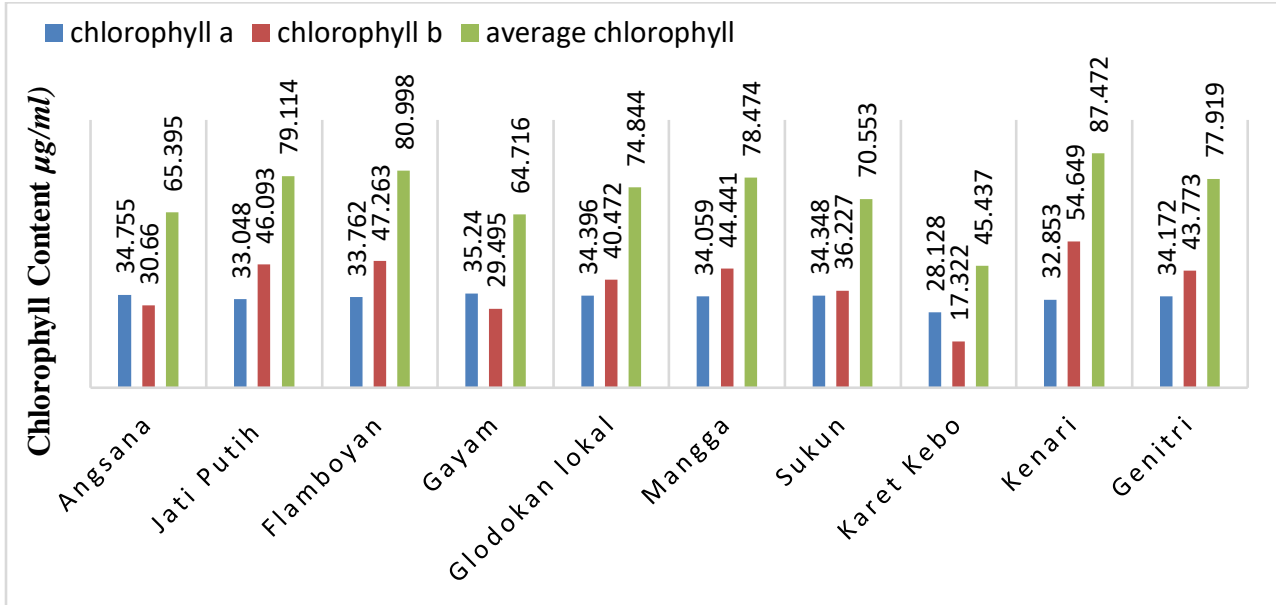

Figure 3. Diagram of leaf's chlorophyll

Bioedukasi Vol. XVII. No. 2 October 2019 


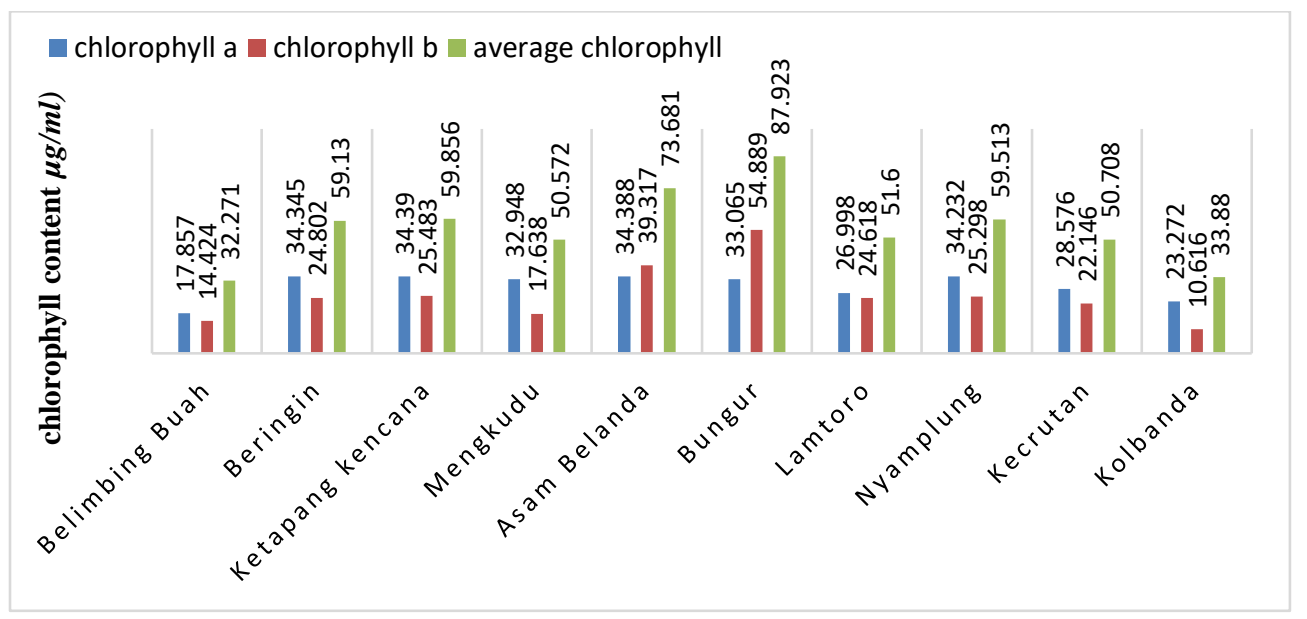

Figure 4. Diagram of leaf's chlorophyll

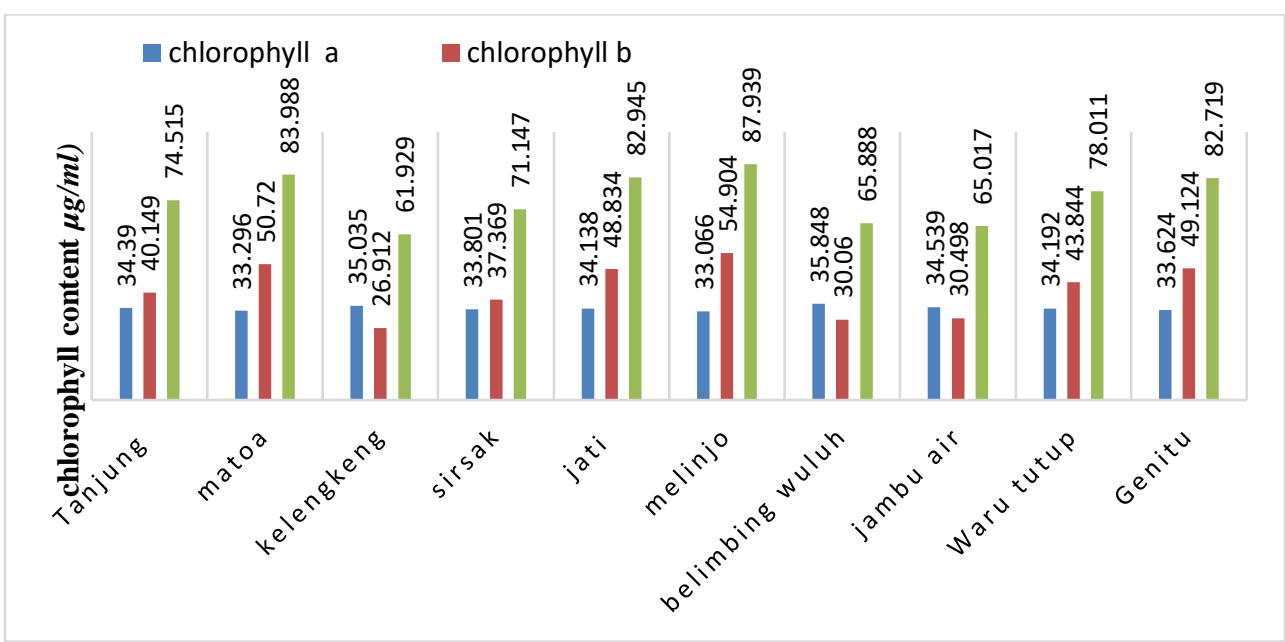

Figure 5. Diagram of leaf's chlorophyll

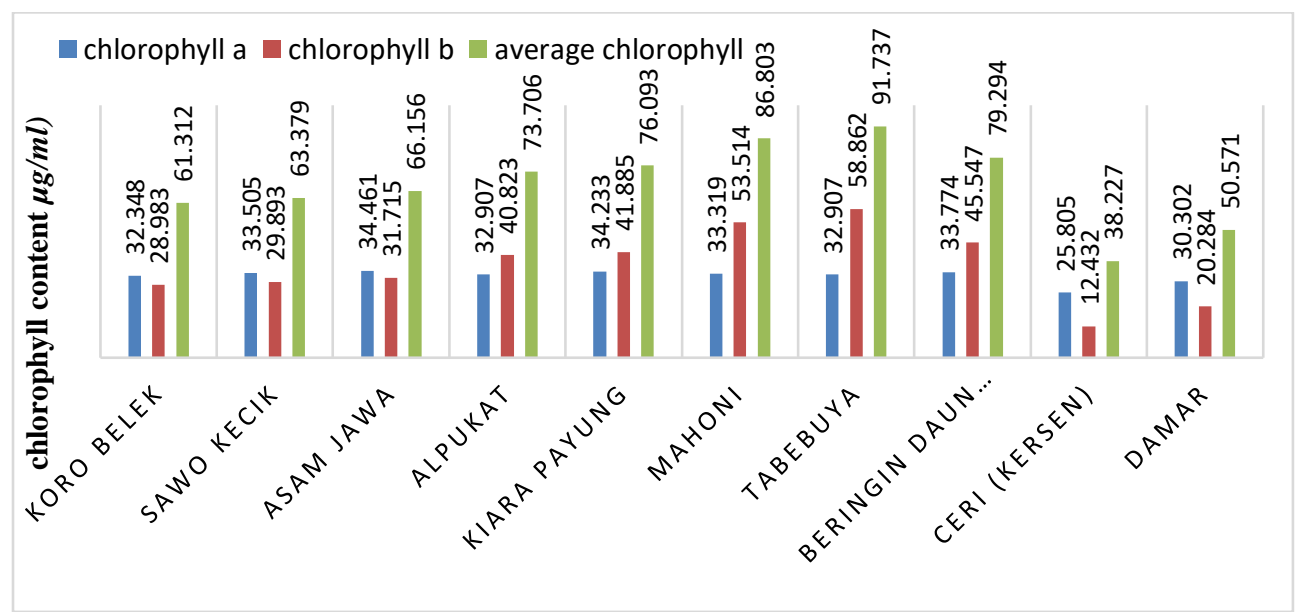

Figure 6. Diagram of leaf's chlorophyll 


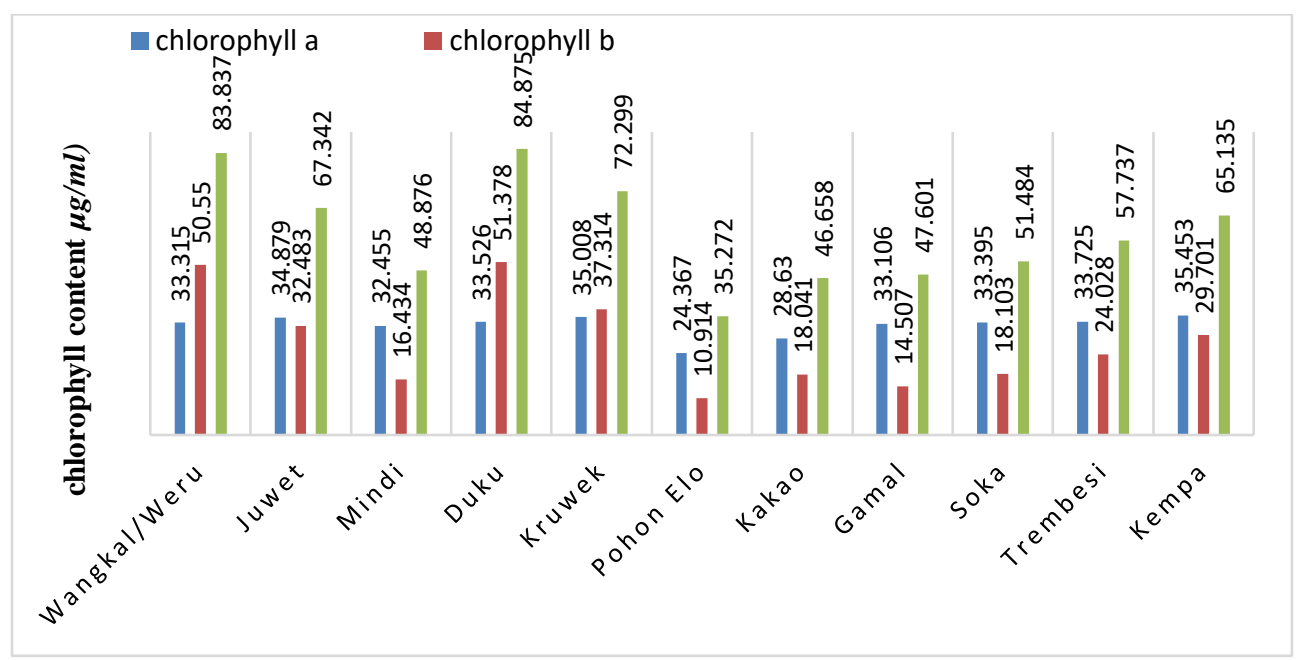

Figure 7. Diagram of leaf's chlorophyll

According to the diagram (Figure 5), the plant with the highest average chlorophyll-a content is Averrhoa bilimbi (belimbing wuluh) with the value of $35.848 \mu \mathrm{g} / \mathrm{ml}$; (Figure 4) while the plant with the lowest chlorophyll-a content is Averrhoa carambola (belimbing buah) at $17.87 \mu \mathrm{g} / \mathrm{ml}$. The diagram in Figure 6 shows that the plant with the highest average chlorophyll $b$ content is Handroanthus sp. (Tabebuya) leaf with chlorophyll b content at $58.862 \mu \mathrm{g} / \mathrm{ml}$. Meanwhile, the plant with the lowest chlorophyll $\mathrm{b}$ content is Araucaria heterophylla (cemara Norfolk) leaf at $9.124 \mu \mathrm{g} / \mathrm{ml}$ (Figure 2).

Diagram in Figure 6 shows that the highest average total chlorophyll content is found on the sample of Handroanthus sp, (Tabebuya) with total chlorophyll content at $91.737 \mu \mathrm{g} / \mathrm{ml}$. The plant with the lowest total chlorophyll content is Araucaria heterophylla (cemara Norfolk), with the total chlorophyll content at 28.517 $\mu \mathrm{g} / \mathrm{ml}$ (Figure 2).

Kurniawan et al. (2010) stated that chlorophyll is a pigment that dissolves in ethanol, methanol, ether, acetone, benzene, and chloroform, but not in water. Apart from chlorophyll $a$ and $b$, there are other types of pigments, such as xanthophyll and carotene. The content of all pigments can be detected by using a spectrophotometer. Prastyo \& Laily (2000) suggest that the higher the concentration, the higher the pigment's sunlight absorbance capacity. The relation between sunlight and the pigment concentration, indicating the thickness of the pigment, is the principle of spectrophotometer measurement.

Spectrophotometer analysis of the chlorophyll contents of plant samples taken from Malabar city forest shows diverse results. The chlorophyll content of each plant is different because the pigment development, including that of chlorophyll, is influenced by various factors. Kusumastuty (2018) suggests that the factors influencing the development of pigments are classified into external and internal factors. The internal and external factors include genetics, sunlight, temperature, soil $\mathrm{pH}$, and nutrient level. Furthermore, Sumenda, Rampe, \& Mantiri (2011) indicate that disruption in one of these factors can contribute to the problem in chlorophyll's bio-synthetic process.

Table 1 presents the measurement and analysis of the physical factors of the Malabar city forest. 
Table 1. Measurement of physics factors of Malabar city forest

\begin{tabular}{clll}
\cline { 1 - 1 } No & Physics factors & & Result \\
\hline 1 & Sunlight intensity & $351 \mathrm{Cd}$ \\
2 & Soil pH level & 6,6 \\
3 & Soil humidity & $3 \%$ \\
4 & Temperature & 29.9 oC \\
5 & Wind speed & $2.5 \mathrm{Knot}$ \\
6 & Air humidity & $62 \%$ \\
\hline (Latifa et al., 2019 ). &
\end{tabular}

In each parameter of the chlorophyll a, chlorophyll b, and total chlorophyll content of each leaf sample, different chlorophyll contents were found. The plants used as samples for the research were plants from the same division, namely Magnoliophyta. However, the genus of each plant observed was different, and therefore, the plants were of different species as well.

Kurniawan et al. (2010) argue that the plant's species determine the chlorophyll's bio-synthesis capacity. This fact is because chlorophyll's biosynthesis is carried out by certain genes in the chromosome, which has a role in the tetrapyrrole biosynthesis (porphyrin core), which is the core of the chlorophyll structure. The content of chlorophyll a is determined by several internal and external factors, including genetics, sunlight, temperature, soil $\mathrm{pH}$, and nutrient level (Kusumastuty, 2018).

Chlorophyll $a$ and $b$ have a significant role in the photosynthesis process. Ai \& Banyo (2011) claim that chlorophyll b holds an important role in the reorganization of photosystem during adaptation against low sunlight quality and intensity. Reflecting on Setiari \& Nurchayati (2009), the chlorophyll b content is closely correlated with the protein level of the chlorophyll, which further gives an impact on the efficiency of photosynthetic antennae function in Light-Harvesting Complex II (LHC II).
The highest average total chlorophyll content in this research was found on Handroanthus sp leaf with the total chlorophyll content at 91.737 , and the lowest was found on A. heterophylla with chlorophyll content at 28.517.

The difference between the total chlorophyll contents of Handroanthus $\mathrm{sp}$ and $A$. heterophylla is very significant. The factor contributing to the difference in total chlorophyll content in these two species is the difference in leaf surface width. Handroanthus sp has a wider leaf surface compared to A. heterophylla, which has a narrow, tube-like leaf shape.

The plants in Malabar city forest were identified to have different divisions and genus. The diversity contributes to the different chlorophyll contents found on each type of plant, which is due to the difference in the biosynthesis process (Widiastuti et al., 2017). The chlorophyll bio-synthesis process is carried out by certain genes within the chromosome. The genes determine the codes for the enzymes crucial in the tetrapyrrole photosynthesis path (porphyrin core), which is the core of the chlorophyll structure (Kurniawan et al., 2010). The fact that each plant has different genetics causes the anatomical and morphological structures to be different, as well. One of the differences that can be found readily is the difference in the leaf's surface width.

Setiawati et al. (2016) suggest that the width of the leaf has a significant role in the photosynthesis process. The width of the leaf's surface determines the photosynthesis result of each plant. The wider leaf surface allows the sunlight absorption to reach the maximum level. The plant with a wider surface can optimize its sunlight absorption, and therefore, the 
chlorophyll content is higher. High chlorophyll content in the leaf correlates with the level of chloroplast in the leaf's cells. More chloroplast cells can readily process photosynthesis with a higher amount of chlorophyll as well. In contrast, a plant with a narrower surface has lower chlorophyll content. This phenomenon can be proven by the results of the analysis of chlorophyll contents of different plants sampled from Malabar city forest, Malang.

It can be seen that the leaf of A. heterophylla and the similar genus had the lowest total chlorophyll content. The low chlorophyll content in these types of plants is assumed to be correlated with the leaf surface, which is considered narrow when compared to other types of plants. The leaf of the plant resembles a needle. The results of research by Setyawati et al., (2016) found the relation between chlorophyll content and Ardisia elliptica leaf's surface width. The research shows that as the leaf surface increases, the chlorophyll content on the leaf consequently rises, continuing until reaching a certain age in different growth levels and decreasing when the plant reaches old age. The leaf surface width correlates positively with the width of the leaf's mesophyll area, and therefore, the chlorophyll content is higher. The leaf mesophyll, especially the palisade tissues, is the tissue rich in chlorophyll (Fahn, 1982; Hopkins, 1997).

Plants in Malabar city forest have different leaf shapes and sizes but generally, have the same green color. The color is closely correlated with the chlorophyll level of the leaf. The leaf color indicates the pigment contents. The leaf pigments generally consist of chlorophyll a and b and carotenoids. Chlorophyll a produces the deep green color in the leaf, chlorophyll $\mathrm{b}$ produces the light green, and carotenoids deliver the red to yellow shades in the leaf (Budiono et al., 2016).

Carotenoid is a pigment that is not visible because of the dominant chlorophyll content. When the chlorophyll content decreases, carotenoids in the leaf start to appear. The chlorophyll level increases during the beginning of growth (vegetative phase), followed by the increase in the surface width and then decreases during the aging phase. The drop happens even when the surface width increases (Hendriyani et al., 2018).

Sunlight intensity is an essential factor in determining chlorophyll content. Based on the identification in this research, sunlight intensity absorbed by each plant was different, and therefore, the chlorophyll contents were also different. The difference was because the sunlight intensity penetrating the leaf crown was different. Generally, the upper leaf crown receives a higher light intensity compared to the leaf crown below. The plants with inferior morphology receive lower light intensity, and thus, the chlorophyll content is possibly lower. Sheltered plants having lower total chlorophyll content found in Malabar city forest are Averrhoa carambola, Bauhinia purpurea, and Pisonia alba Spanoghe.

Budiono et al., (2016) proved that the higher the light intensity absorbed, the higher the chlorophyll content. In contrast, Salisbury \& Ross (1995) suggest that light intensity, which is too high, can result in a decrease in chlorophyll level. Wibowo et al. (2017) mention that the cause of the decrease is the broken chlorophyll, whose reaction is called photo-oxidation.

Temperature is an environmental parameter which has a crucial role in the enzymatic reaction. Each plant has a different optimum temperature, which is 
contributed by light intensity and humidity. The higher the light intensity, the higher the temperature (Budiono et al., 2016). Consequently, the humidity gets lower. Plants living in an environment with optimum temperature and humidity have better growth because the photosynthesis process runs well. To put it simply, an optimum photosynthesis process guarantees the increase of chlorophyll level.

The $\mathrm{pH}$ level is one of the physical parameters which support the plant's growth. The level of $\mathrm{pH}$ indicates the activity of hydrogen ions, which can be classified into acid and base. The optimum $\mathrm{pH}$ level of plants varies from 5.5 to 7.5 (Taufiq \& Sundari, 2012).

The soil $\mathrm{pH}$ level can affect the micro-organism activity. The soil with $\mathrm{pH}$ level indicating base condition tends to have a nutrient deficiency, such as nitrogen deficiency. The decrease of certain nutrients in the soil affects the performance of the enzymes and consequently affects the photosynthesis process (Isnadina \& Hermana, 2013). The effect is that it can disrupt the chlorophyll synthesis process and therefore obstruct the process of the cell, tissue, and organ developments.

The decrease of nitrogen level can affect the photosynthesis process, which might result in a decrease in chlorophyll level and the photosynthesis enzymes. Lacking this nutrient can cause the plant to exhibit chlorosis symptoms.

Chlorophyll is sensitive to drought stress because drought can disrupt the formation of proto-chlorophyll and eventually decrease the chlorophyll content of a plant (Ai, 2011).

Environmental changes can affect the process of chlorophyll synthesis. These environmental changes could be in the form of industrial or vehicle pollution. Malabar city forest in Malang is exposed to vehicle pollution, which comes from different directions. The plants, thus, have a high sensitivity to air pollution. There are many pollutantacute sensitive, -sensitive, and -less sensitive plants in this city forest (Hidayati, 2009).

Chlorophyll is sensitive and can be readily affected by the pollutant from a certain time and level. The relation between the chlorophyll content and pollutant is inversely proportional. Emission from vehicles can affect the chlorophyll content, and when this happens, a high concentration of pollutants can infiltrate the leaf's tissues, disrupting the supply of $\mathrm{Mg}$ and $\mathrm{Fe}$, which are the main components of chloroplast (Sembiring \& Sulistyawati, 2006). This triggers the possibility of competition of the pollutant ions and iron (Fe) to bind with porphyrin (Muntadhiroh, 2015). The competition inhibits Fe-porphyrin which is the precursor of Mg-porphyrin bind (Ulfah et al., 2017).

Each plant has different capacities in absorbing pollutants. The plants with wider leaf surface and leaf hair have better pollutant absorption capacity compared to other types of plants. Muntingia calabura is an example of a good pollutant absorptive plant. This is proven by the analysis of chlorophyll content, which shows that Muntingia calabura's leaf has a lower chlorophyll level. The leaf has a rough surface with fine hair, which allows pollutants to stick and infiltrate into the leaf's tissue. The high level of pollutants contained inside the leaf, cause the chlorophyll content to decrease because of the toxic. A pollutant can infiltrate the leaf's tissue through the stomata because the size of the pollutant is finer than the size of the stomata. A pollutant can also passively infiltrate the tissue as it binds with $\mathrm{CO} 2$. 


\section{CONCLUSIONS}

The highest average of chlorophylla content is on the leaf of Averrhoa bilimbi $(35,848 \mu \mathrm{g} / \mathrm{ml})$, while the lowest is on Averrhoa carambola $(17,857$ $\mu \mathrm{g} / \mathrm{ml})$. The highest average of chlorophyll b content is in Handroanthus sp $(58,862 \mu \mathrm{g} / \mathrm{ml})$, while the lowest is Araucaria heterophylla $(9,124 \mu \mathrm{g} / \mathrm{ml})$. Lastly, the highest average of total chlorophyll content is in the leaf of Handroanthus sp (91,737 $\mu \mathrm{g} / \mathrm{ml}$ ), while the lowest is in the leaf of Araucaria heterophylla (28,517 $\mu \mathrm{g} / \mathrm{ml})$.

\section{ACKNOWLEDGMENT}

The researchers would like to express appreciation to the Dean of Faculty of Teacher Training and Education as well as the Rector of the University of Muhammadiyah Malang for the support in completing this research project.

\section{REFERENCES}

Ai, N. S. (2011). Biomassa Dan Kandungan Chlorophyll Total Daun Jahe (Zingiber officinale L) yang mengalami cekaman kekeringan. Jurnal Ilmiah Sains, 11(1), 1-5.

Alfian, rizal \& Kurniawan, Hendra. (2010). Identifikasi bentuk, struktur dan peranan huta Kota Malabar Malang. Bioma sains. 10(2): 195201.

Ardiyanto, F. M., Karyawati, A. S., \& Sitompul, S. M. (2017). Pengaruh frekuensi pemberian dan komsentrasi Rhizobakteri pemacu perumbuhan tanaman terhadap pertumbuhan dan hasil kedelai sayur (Glycine max L . Merrill). Jurnal Produksi Tanaman, 5(11), 17621767.
Budiono, R., Sugiarti, D., Nurzaman, M., Setiawati, T., Spriatun, T., \& Mutaqien, A. Z. (2016). Kerapatan stomata dan kadar chlorophyll tumbuhan Clausena excavata berdasarkan perbedaan intensitas cahaya. In Seminar Nasional Pendidikan dan Saintek (pp. 61-65). Sumedang: Program studi Biologi FMIPA Universitas Padjajaran. https://doi.org/10.1055/s-2005865601

Campbell. (2008). Biologi. Jakarta: Erlangga.

Dahlan, A. (1992). Kependudukan, Lingkungan dan Pembangunan Berkelanjutan ArahPerkembangan dan Kebijaksanaan. Serasi No. 22. Jakarta.

Dolman, A..J., A. Verhagen and C.A. Rovers. (2003). Global Environmental Change and Land Use. Kluwer Academic Publishers Dordecht/ Boston/ London.

Fahn, A. (1982). Anatomi Tumbuhan. Gadjah Mada University Press

Faqir, Al. S. (2010). Manfaat Chlorophyll Bagi Kesehatan. Http://hsudiana.wordpress.com/ 2010/11/12/manfaat-chlorophyllbagi-kesehatan. Diakses pada tanggal 12 Agustus 2019.

Hakim. (1991). Pemeliharaan Tanaman. Penebar Swadaya. Jakarta.

Hendriyani, I. S., Nurchayati, Y., \& Setiari, N. (2018). Kandungan chlorophyll dan karotenoid Kacang Tunggak (Vigna unguiculata (L.) Walp.) pada umur tanaman yang berbeda. Jurnal Biologi Tropika, 1(2), 
https://doi.org/10.14710/jbt.1.2.3843

Hendriyani, I. S., \& Setiari, N. (2009). Kandungan chlorophyll dan pertumbuhan kacang panjang (Vigna sinensis) pada tingkat penyediaan air yang berbeda. Artikel Penelitian, 17(3), 145-150.

Hidayati, S. R. (2009). Analisis karakteristik stomata, kadar chlorophyll dan kandungan logam berat pada daun pohon pelindung jalan kawasan lumpur porong sidoarjo. Universitas Islam Negeri Maulana Malik Ibrahim Malang. Retrieved from http://etheses.uinmalang.ac.id/995/

Hopkins, G. H. (1997). Introduction to Plant Physiology. John Wiley \& Sons. Inc.

Irwan, D. Z. (1994). Peranan Bentuk dan Struktur Kota terhadap Kualitas Lingkungan Kota. Disertasi, Pascasarjana Institut Pertanian Bogor. Bogor.

Isnadina, D. R. M., \& Hermana, J. (2013). Pengaruh konsentrasi bahan organik, salinitas, dan $\mathrm{pH}$ terhadap laju pertumbuhan alga. In Seminar Nasional Pascasarjana XIII-ITS.

Kurniawan, M., Izzati, M., \& Nurchayati, Y. (2010). Kandungan chlorophyll, karotenoid, dan vitamin $\mathrm{C}$ pada beberapa spesies tumbuhan akuatik. Buletin Anatomi Dan Fisiologi, 18(1). https://doi.org/10.14710/baf.v18i1.2 614

Kusumastuty, D. A. (2018). Analisis perubahan morfologi dan kadar korofil pada tanaman kersen
(Muntingia caabura L.) di Area Pertambangan Minyak Bumi Wonocolo Kabupaten Bojonegoro. Instituonal Repository, UMM. Universitas Muhammadiyah Malang. Retrieved from http://eprints.umm.ac.id/38097/3/B AB II.pdf

Latifa, Roimil \& Fatmawati, Diani. (2018). Keanekaragaman Morfologi Tajuk Pohon dan Stomata Daun untuk Mengabsorpsi Karbon Dioksida di Hutan Kota Malabar Kota malang. Penelitian Dasar Keilmuwan. Lembaga Penelitian UMM.

Li, R., P. Guo, M. Baum, S. Grando, S. Ceccarelli. (2006). Evaluation of Chlorophyll Content and Fluorescence Parameters as Indicators of Drought Tolerance in Barley. Agricultural Sciences in China. 5(10): 751-757.

Muntadhiroh, C. (2015). Karakteristik anatomi dan potensi daun trembesi (Albizia saman (Jacq.) Merr.) di Ruas Jalan Kota Malang sebagai akumulator logam berat timbal $(\mathrm{Pb})$. Universitas Islam Negeri Maulana Malik Ibrahim Malang. Retrieved from

https://r.search.yahoo.com/_ylt=Aw rx5kofKDRdYO8A2B33RQx.; ylu $=\mathrm{X} 3 \mathrm{oDMTBycWJpM} 21 \mathrm{vBGNvbG8}$ Dc2czBHBvcwMxBHZ0aWQDBH NlYwNzcg-$/ \mathrm{RV}=2 / \mathrm{RE}=1563728031 / \mathrm{RO}=10 / \mathrm{RU}$ $=$ http $\% 3 \mathrm{~A} \% 2 \mathrm{~F} \% 2 \mathrm{Fetheses}$.uinmalang.ac.id\%2F $2984 \% 2 \mathrm{~F} 1 \% 2 \mathrm{~F} 10$ 620074.pdf/RK=2/RS=DzqWcMZzj smDmxsuHEUfJcQQFIM-

Nintya Setiari and Yulita Nurchayat. (2009). Eksplorasi Kandungan Chlorophyll pada beberapa Sayuran 
Hijau sebagai Alternatif Bahan Dasar Makanan Tambahan. BIOMA. 11 (1): 6-10.

Nurrohman, Endrik., Zubaidah, Siti., Kuswantoro, Heru. (2017). Perawakan Beberapa Genotipe Kedelai (Glycine max (L.) Merr) Tahan Cowpea Mild Mottle Virus (CPMMV) Dengan Variasi Dosis Nitrogen. Prosiding Seminar Nasional III Pendidikan Biologi FKIP dan PSLK UMM.

Perwitasari, B., Tripatmasari, M., \& Wasonowati, C. (2012). Pengaruh media tanam dan nutrisi terhadap pertumbuhan dan hasil tanaman pakchoi (Brassica juncea L.) dengan sistem hidroponik. Agrovigor, 5(1), 14-25. Retrieved from http://journal.trunojoyo.ac.id/agrovi gor/article/view/304

Prastyo, K. A., \& Laily, A. N. (2000). Uji Konsentrasi chlorophyll daun temu mangga (Curcuma mangga Val.), temulawak (Curcuma xanthorrhiza), dan temu hitam (Curcuma aeruginosa) dengan tipe kertas saring yang berbeda menggunakan spektrofotometer leaf chlorophyll concentration test of curcuma. In Seminar nasional konservasi dan pemanfaatan sumber daya alam 2015 (pp. 188-191).

Pratama, Jaya andi \& Nikmati, Ainun Laily. (2015). Analisis Kandungan Chlorophyll Gandasuli (Hedychium gardnerianum Shephard ex KerGawl) pada Tiga Daerah Perkembangan Daun yang Berbeda. Prosiding Seminar nasional konservasi dan pemanfaatan sumberdaya alam. Pendidikan Biologi, Pendidikan Geografi,
Pendidikan Sains, PKLH - FKIP UNS.

Salaki. (2000). Biologi sel. Proyek Pengembangan Perguruan Tinggi Indonesia Timur Kerjasama Universitas Sam Ratulangi Canadian Internasional Development Agency Simon Fraser University

Salisbury, F. B., \& Ross, C. W. (1995). Fisiologi tumbuhan. Bandung: ITB.

Sembiring, E., \& Sulistyawati, E. (2006). Akumulasi $\mathrm{Pb}$ dan pengaruhnya pada kondisi daun Swietenia macrophylla King (pp. 17-18). Retrieved from https://s3.amazonaws.com/academia .edu.documents/31136893/7._Ebinth alina_IATPI2006.pdf?responsecontent-disposition=inline $\% 3 \mathrm{~B}$ filename\%3DAkumulasi_Pb_dan_p engaruhnya_pada_kondis.pdf\&XAmz-Algorithm=AWS4-HMACSHA256\&X-AmzCredential=AKIAIWOWYYGZ2Y5 3UL3A\%2F2

Setiawati, Tia., Afrylylya Saragih, Irene., Nurzaman, Mohamad., Zainal Mutaqin, Asep., (2016). Analisis Kadar Chlorophyll dan Luas Daun Lampeni (Ardisia humilis Thunberg) pada Tingkat Perkembangan yang Berbeda di Cagar Alam Pangandaran. Prosiding Seminar Nasional MIPA 2016 "Peran Penelitian Ilmu Dasar dalam Menunjang Pembangunan Berkelanjutan". Departemen Biologi, Fakultas MIPA, Universitas Padjadjaran, Bandung

Sukmasari, M. D., Wijaya, A. A., Dani, U., \& Budi, W. (2018). Respon sembilan varietas kedelai yang ditanam pada kondisi jenuh air. 
Agronomika, 12(2), 87-91. Retrieved from https://journal.uniba.ac.id/index.php /AGR/article/view/89/85

Sumenda, L., Rampe, H. L., \& Mantiri, F. R. (2011). Analisis kandungan chlorophyll daun mangga (Mangifera indica L.) pada tingkat perkembangan daun yang berbeda. Bioslogos, 1(1), 20-24.

Suryaningsih, C., Santoso, S. J., \& Hardiatmi, J. S. (2017). Pengaruh Macam Limbah Minuman Dan Komposisi Media Tanam Terhadap Pertumbuhan Dan Hasil Tanaman Sorgum.

Sasmitamihardja D, Siregar A. (1997). Fisiologi tumbuhan. Jurusan Biologi FMIPA - ITB. Proyek Pendidikan Tenaga Akademik Direktorat Jenderal Pendidikan dan Kebudayaan, Bandung.

Suyitno. (2008). Modul praktikum pengayaan materi. Jurusan Pendidikan Biologi Fakultas Matematika Dan Ilmu Pengetahuan Alam Universitas Negeri Yogyakarta.

Taufiq, A., \& Sundari, T. (2012). Respons tanaman kedelai terhadap lingkungan tumbuh. Buletin Palawija, 26(23), 13-26.

Ulfah, M., Rachmadiarti, F., \& Rahayu, Y. S. (2017). Pengaruh timbal (Pb) terhadap kandungan chlorophyll kiambang (Salvinia molesta ). Lentera Bio, 6(2), 44-48. Retrieved from https://jurnalmahasiswa.unesa. ac.id/index.php/lenterabio/article/vie w/19457
Wibowo, S. A., Sunaryo, Y., \& P, D. H. (2017). Pengaruh Pemberian Naungan Dengan Intensitas Cahaya Yang Berbeda Terhadap Pertumbuhan Dan Hasil Berbagai Jenis Tanaman Sawi (Brassica juncea L.). Ekp, 13 (3), 1576-1580.

Widiastuti, S., Ahmad, A., \& Hala, Y. (2017). Potensi CO2+ terhadap Peningkatan Aktivitas Chlorophyll Sebagai Antioksidan Pada Alga Hijau Halimeda discoida. 